\title{
Role of Sales Promotion Techniques in Building Consumer Preferences: A Study of FMCG Products of Selected Brands in Dehradun City of Uttarakhand
}

\author{
Suchita Gera \\ Assistant Professor, Department of Management \\ Himgiri Zee University,Uttarakhand, India
}

\begin{abstract}
The importance of sales promotion in marketing mix is unquestionable. Sales Promotion techniques areconsider one of the important tools and technique for increasing the sales volume. Considering the cost of sale promotions are always substantial, the selection and design of most effective and efficient promotion tools are crucial for a successful promotion campaign. The ability of marketers to identify attributes which are relevant to their target market is vital for them to have better control over the results of their promotional activities. The present paper aims to evaluate the possibility of consumer preference due to sales promotion, effectiveness of sales promotion tools in motivating purchase in FMGC sector and on this basis of study few suggestions are offered that will be useful formarketing managers of FMCG companies to streamline their sales promotion strategies and make their promotional efforts more successful.
\end{abstract}

Keywords: Sales promotion, marketing mix, FMGC, Consumer preference 


\section{Introduction}

Sales promotion as an essential element of marketing synthesis has remained severely used as a main enticement instrument to attract customers to provisions and upsurge sales volumes. Scholars have continuously projected a variation of ideas to demonstrate in what way sales promotion can move consumer buying behavior. Though sales promotion has turn out to be an omnipresent component of marketing, big percentages of unsuccessful promotional events specify an inordinate necessity of filtering and readdressing the emphasis of the bearing foundations. Sales promotions include a diversity of short-range promotional methods intended to persuade consumers to react, the common sales promotions are in a straight line linked with product buying. These preferment are proposed to improve the worth of a product bought by either dropping the total price of the product or by accumulation of additional value to the ongoing acquisition price i.e., get more value for the money.

\section{Sales Promotion for FMCG}

Sales promotion in FMCG businesses is used to generate a provisionalmotivation on the sales of a brand by creating consumers a superiorproposition. This publicityincentive is portion of the marketing propositioncomplete up of aspects like product topographies and paybacks, worth, accessibility, customer service and superiority. Customers are anticipated to turn on this proposal which can have an instantoutcome on the sales proportion of a business. The fast moving consumer goods market isobservingincreasing use of sales promotion accomplishments all over the world. The market is categorized by goods having small unit value thus repeatedlyprocured and consumer behaviorimitating smaller amountfidelity, instinctpurchasing, and littleparticipation by the customer. A customer'schoice of what brand to purchase with how much quantity be subject to brand factors like price, promotion etc. and customer explicit factors like consumer's brand loyalty, consumption rate, product inventory, and sensitivity to price and promotion. 


\section{Techniques of Sales Promotion}

Sales promotion incorporates multiple interim promotional techniques which is for the common customers, this promotion is reinforced by advertising, publicity, direct selling etc. This kind of sales promotion is focused towards the end customers. Sales promotion techniques are always a "pull strategy" which inspires the customer for buying the desired brand or product. The promotion strategies which are generally used are:

- $\quad$ Free sample

- Trial

- Gift and coupons

- Loyalty rebates

- Coupons and lucky draw

- $\quad$ Price discount

\section{Review of Literature}

Praveen Agarwal and Rajeev Vaidyanatan (2013)in their examination on purchase speed increase impacts of time-restricted advancements investigated the effect of retail advancements on buy speed increase and report results from two examinations. In their first investigation, it was set up that advancements of brief period, for example, store coupons, speed up buys, though advancements of longer span, like producer's coupons, have no such effect. In the following investigation, the effect of semantic prompts was inspected featuring the timerestricted nature of advancements, for example, '10 Hours Only Sale', sway on buy ability, goal to look further for arrangements and mentalities towards the arrangement.

D. E. Schultz and Martin. P. Block (2014) states in their examination that four driving deals limited time instruments, in view of buyer impact were coupons, home examples, in-store tests and retail customer cards. Customer cards had most impact on acquisition of auxiliary, not essential brands in classes. Customer cards are an unmistakably underused limited time device in building brand inclination and deals.

Teck WengJee and Cyril de Run Ernest (2013) in conversation of buyers' very own qualities and deals advancement inclinations impact on conduct expectation and buy fulfillment 
for purchaser item, contends that business advancement strategy inclinations will affect customers' social aim and buy fulfillment for all the item types examined. Then again, there is no huge effect in buyers' buys fulfillment and conduct goal by close to home estimation for all the item type contemplated.

Zhanting Yang (2009)in her investigation of reports that the promotions which Tesco Lotus at present utilizes are free examples, pamphlets, get one-get-one free, markdown coupon, cost off, at the counter presentation, participation program, show, cash-back, and packaged free preliminary advancements. Purchase one get without one advancements are among the most preferred and best of the advancement techniques utilized and sweepstakes and at the counter presentation advancements are among the most un-enjoyed and most disastrous of advancements utilized, demonstrating that advancements which are destined to impact shopper buying conduct are advancements which customers like. The discoveries likewise show that there are joins between segment attributes and customer buying conduct.

Soni Neha and VergheseManoj (2013)deduced in their examination that business advancement devices assumes huge part in customer buy choice. The respondents are most impacted by offer additionally followed by premium and challenge while value pack and discount have been discovered to be unimportant. The advertisers should zero in on reexamining of the above devices for animating buy choice.

Youneset. al. (2019)the investigation discoveries recognized that, as per all respondents, the accompanying deals advancement devices strongly affected shoppers' buying choices: plan and plan of grandstands among the read apparatuses for marketing; purchase 1 and get 2, and limits among the read instruments for buyer advancement; and blessings among the exchange advancement contemplated devices. The discoveries showed that similar apparatuses were named as the most widely recognized by all respondents. The instrument free example of elevated items gave off an impression of being the most common, be that as it may, simultaneously, was the most un-successful. 
Dr. G. Yashodha (2019)in her examination demonstrates that business advancement procedures, for example, Cash limits, unconditional present, bargain inclination and additional amount assume a critical part in impacting the purchaser's buy choice. The exploration discoveries additionally show that buyer's choice is likewise impacted by different factors like value, amount, quality, shading, scent, fulfillment, occasional impact, accessibility and notice. Accordingly the FMCG organizations that are competing to arrive at the clients should be mindful so as to meet the normal saw advantages of these forthcoming clients.

Preeta $\mathbf{H}$ Vyas (2005) in her examination infers that business advancement offers which are exceptional and offers quick value motivating forces is probably going to engage all fragments. Another method of noticing the examination is that possibly a conduct or psychographic method of fragmenting may assist advertiser with drawing in clients towards deals advancement offers.

\section{Objectives of the Study}

1. To study the consumer preference because of sales promotion.

2. To analyze the impact of sales promotion techniques inencouragingbuying.

3. To offer a few suggestions on how to improve sales promotion Strategy.

\section{Hypothesis of the Study}

Ho (1): There is no significant difference in the impact of important sales promotion techniques in customer preferences.

Ha (1): There is significant difference in the impact of important sales promotion techniques in customer preferences.

\section{The Research Problem}

Sales promotion deals with encouraging buying by givingan inducement to the integral features of the product or services presented. Maximum sales promotions have apreciseperiod. 
They give results very fast but when the publicity isfinished thatstimulus make sales tend to spilloff. A properlyintendedpreparation of sales promotion canattainmany objectives like motivate customer preferences, adoptiveaugmentedbuying andreparationrepeatedbuying. Sale promotion often fallouts in big sales result for a promoted article.Sales promotion technique is one of the methods that help FMCG companies to get animproved marketshare for its feasibleprogress. The current study is a stride in this direction. Explicitly it inspectsthe opportunity of developing the customer preferences due to sales promotion and measures thesuccess ofpromotion tools in inspiringbuying. Henceforth, this study has been originated to propose a fewrecommendations to marketers on how to improve their consumer sales promotion strategy.

\section{Research Methodology}

The study is deliberate as a descriptive constructed on primary andsecondary data. The research is largelyconstructed on primary data composed from consumers of FMCG in Dehradun city of Uttrakhand state. Secondary data linking to the study have been poised from several Journals, Textbooks, Periodicals and Dailies. For the determination of gathering data aQuestionnaire and Structured Interview Schedule were used. Theresearcher collected data from the respondents directly through an open personal interview. Multistage sampling method was implemented to make choice of the essential numberof respondents from diverse parts of Dehradun city. The city wasdistributed into two equivalentfragments on the basis of number of income area. Fromrespectivearea200 respondent were selected district 200 respondents were selected. Overall there are 400 respondents who characterize a cross section of customers of fast moving consumer goods inDehradun. Tocomprehend the reliability of data, measured and arithmetical tools such as Percentages, Standard Deviation, Mode, t-test etc. were used.

\section{Analysis and Interpretation}

Consumer sales promotion of FMCGs has equallyimmediate and longterm goals. Shortterm objectives include warding off resentment by filling the consumers,preferences of the brand in an enormouslyuncertain market and dissipating out stock for the duration of theoff-season. Long-term goalscomprisestructure brand image, loyalty and category extension.Positive sales promotion makesextraincome to the marketer or supports to upholdexistingrevenue. Four 
products, demonstrating four vitalclassifications of FMCG, have been carefully chosen to studythe result of sales promotion on customer's buying and consumptionbehavior. These products are Coffee, Shampoo, Pulsesand Soap.

\section{Consumer Preference Due to Sales Promotion}

Consumer preference is one of the supreme aim ofsales promotions in FMCG segment. This is essential when a new brand ispresented in anextremelymodest market where dispersion in to the market is probable only by giving some eye-catchingdeals. Issuingtrials of the merchandise, providing gifts and freebees and givingprofoundrebates are few of the techniquesusuallytake on by the company to attain this objective. It is also likely that the customers of a product purchase its alternates if it is appropriatelyindorsed. For instance, irregularpurchasers of coffee may purchase an appealingly promoted brand of the product in coffee or beside with his consistent beverage of coffee; consistentcustomers of soapmay buy shampoo; purchasers of unbranded pulses may purchase a promoted brand of the product;andusers of soap powder or cake may switch over to soap. This occurrence, which is also calledcategory expansion, is a module of trial purchase.

Customer'slikelihood of making a preference of the particular products under sales promotion propositions was measured and logged in terms of confident levels or degrees. Consequently there are fivedifferent groups of consumers: - (1) customers who will never make a preference of a promotedbrand; (2) consumers whose possibility of making a preference is less than 25 percent; (3)consumers whose possibility of making a preference is 25 to 50 percent; (4) consumers whosepossibility of making a preference is 50 to 75 percent; and (5) consumers whose possibility ofmaking a preference is above 75 percent. For the suitability of examination and recording the saidgroups were retitled as 'no possibility group', 'very low possibility group', low possibility group’'high possibility group’ and very high possibility group’ respectively. The subsequent table covers data concerning to the customer'slikelihood of making a preference of the promoted brand of coffee,shampoo, pulses and soap. 
Table 1:Possibility of Making Preference Due to Sales Promotion

\begin{tabular}{|l|l|l|l|l|l|l|l|l|}
\hline $\begin{array}{l}\text { Level of } \\
\text { Possibility }\end{array}$ & \multicolumn{2}{l}{ Coffee } & \multicolumn{2}{l}{ Shampoo } & \multicolumn{2}{l}{ Pulses } & \multicolumn{2}{l|}{ Soaps } \\
\hline & No. & $\%$ & No. & $\%$ & No. & $\%$ & No. & $\%$ \\
\hline No Possibility & 280 & 70 & 251 & 62.75 & 294 & 73.5 & 240 & 60 \\
\hline $\begin{array}{l}\text { Very Low } \\
\text { Possibility }\end{array}$ & 86 & 21.5 & 79 & 19.75 & 74 & 18.5 & 89 & 22.25 \\
\hline Low Possibility & 14 & 3.5 & 43 & 10.75 & 10 & 2.5 & 36 & 9 \\
\hline High Possibility & 11 & 2.75 & 15 & 3.75 & 9 & 2.25 & 17 & 4.25 \\
\hline $\begin{array}{l}\text { Very High } \\
\text { Possibility }\end{array}$ & 9 & 2.25 & 12 & 3 & 13 & 3.25 & 18 & 4.5 \\
\hline Total & 400 & 100 & 400 & 100 & 400 & 100 & 400 & 100 \\
\hline Mode & 1 st item & & 1 st item & & 1 st item & 1 st item \\
\hline
\end{tabular}

Source: Survey Data

The table 1 provides the subsequentstatistics:

Coffee:Customer'slikelihood of making a preference of anendorsed brand of coffee is either zero or very low. 70 percent respondents are of the opinion that there is no likelihood of buying a newbrand or the merchandise for the first time due to an offer and 21.5 percent ranted that there is very lowpossibility in their case. Higher-level likelihoods are very inadequate. As the prototypicalassessment is calculated as the first item it can be established that there is no likelihood of preference of coffee because ofa promotional offer.

Shampoo: The likelihood of making a preference of a promoted brand of shampoo is greaterthan that of coffee as is shown in the table. While 62.75 percent of respondents answered relatively negative, 19.75 and 10.75 percent of respondents showed that there is 'very low' and 'low'likelyhood.It can be determined that there is no likelihood of Consumer preference of shampoo because of a promotional offer.

Pulses:Outcomes of study are muchrelated to that of coffee. 73.5 percent respondents are of the view that there is no likelihood of creating a preference of a brand or the product for the first 
time due to aproposition and 18.5 percent speak out that there is very low likelihood in their situation. The outstanding 8 percent respondents arepositive of building a preference. It can be established that there is no possibility of Consumer preferenceof pulses because of apromotional offer.

Soap:Concentratedlikelihood of preference is there in the case of this merchandise. The segment ofrespondents who are not at all fascinated in building a consumer preference is 60 percent. 22.25, 9, 4.25 and 4.5 percent of respondents specified very low, low, high and very high likelihoods of building a consumer preferencecorrespondingly when the product is put on promotional offer. Hence it can be established that there is no likelihood of consumer preference ofsoapdue to a promotional offer.

From the precedingargument it is clear that soap is the product that is subject to extremeconsumer preference occurrences followed by shampoo, pulses and coffee. Numerousstages of likelihoods of consumer preference are also dissimilar according to the type of product.

\section{Effectiveness of Sales Promotion Tools in Motivating Preference}

However the likelihood of preference of FMCG due of sales promotion, is very restricted it issubstance to study the impact of several sales promotion apparatusesindependently in appealing preference.Promotional plans can be reformed by choosingsuitable tools that is accomplished of motivating the consumers to try new products or brands in the place of an alternative product or different brand. So it is very vital to distinguish which of the consumer sales promotion techniques arecreating a mind set in customers to make preference in the case of FMCG segment. Respondents who were seeninterested to try new products or brands due to salespromotion were requested to give their preferences of promotional tools by allocating 100 points. Themean and standard deviation of these marks were acquired in order to classify and rank these toolsin their order of appropriateness. Table 2 deliversstatistics with relate to the four products on thisaspect of study. 
Table 2:Effectiveness of Sales Promotion Tools in Motivating Preferences

\begin{tabular}{|c|c|c|c|c|c|c|c|}
\hline Product & No. & Statistic & $\begin{array}{l}\text { Price- } \\
\text { Off }\end{array}$ & Couponing & Premium & Sampling & POP \\
\hline \multirow[b]{2}{*}{ Coffee } & \multirow[b]{2}{*}{104} & Mean & 33.042 & 13.9 & 18 & 15.34 & 14.6 \\
\hline & & S.D. & 23.34 & 9.53 & 12.8 & 13.32 & 12.77 \\
\hline \multirow[b]{2}{*}{ Shampoo } & \multirow[b]{2}{*}{136} & Mean & 28.64 & 13.48 & 20.79 & 17.2 & 17.63 \\
\hline & & S.D. & 20.64 & 8.66 & 15.35 & 12.16 & 18.19 \\
\hline \multirow[b]{2}{*}{ Pulses } & \multirow[b]{2}{*}{112} & Mean & 30.22 & 15.34 & 16.22 & 17.24 & 19.01 \\
\hline & & S.D. & 21.73 & 9.73 & 13.29 & 14.84 & 17.34 \\
\hline \multirow[b]{2}{*}{ Soap } & \multirow[b]{2}{*}{147} & Mean & 30.36 & 12.38 & 18.22 & 17.11 & 18.43 \\
\hline & & S.D. & 23.48 & 11.62 & 14.85 & 15.21 & 18.22 \\
\hline
\end{tabular}

The table reveals the following information:

Coffee: In the instance of coffee, 104 respondents were seeninterested by sales promotion to preferences of the merchandise or a specific brand of the product. 'Price-off' is utmostoperative salesPromotion tool in inspiringpurchasers to favor the product for the first time or after the gap of aequitable period or a new brand of coffee for an current user. Its mean score is 33.042 with a standard deviation of 23.34, which is in the satisfactoryperimeter. 'Premium' (mean value 18.0), 'sampling' (mean value 15.34), 'POP' (mean value 14.60) and 'couponing' (mean value 13.90) can be organized in the direction of their influence to encouragepurchasers in building preference.

Shampoo: In the incident of shampoo, 136 respondents were set upinspired by sales promotion to build up a preference of the product or a specific brand of the product. 'Price-off' with a mean score of 28.64 is the utmost effective sales promotion device in appealingpurchasers to try the product for the first time or after the gap of a reasonable period or a new brand of shampoo for an current user. 'Premium' (mean value 20.79), 'POP' (mean value 17.63), 'sampling' (mean value 17.2) and 'couponing' (mean value 13.48). 
Pulses: In the instance of pulses, 112 respondents were establishinterested by sales promotion to maketrial purchase of the product or a specific brand of the product. 'Price-off' with a mean score of 30.22 is the furthermostin effect sales promotion tool in appealingpurchasers to try the product for the firsttime or after the gap of a rational period or a new brand of pulses for an current user. 'POP’(mean value 19.01), 'sampling' (mean value 17.24), 'Premium' (mean value 16.22) and'couponing'(mean value 15.34) can be arranged.

Soap: In the event of soap, 147 respondents were establishinterested by sales promotion tomake trial buying of the product or a specific brand of the product. 'Price-off' with a mean scoreof 30.36 is the most active sales promotion tool in encouragingpurchasers to try the merchandise for thefirst time or after the gap of a rational period or a new brand of soap for an current user. 'Premium' (mean value 18.22), 'POP' (mean value 18.43), 'sampling' (mean value 17.1), and'couponing' (mean value 12.38) can be organized in the order of their supremacy to inspirecustomers.

To encapsulate the above argument, 'price-off' is the superlative and 'couponing' is the lowest effective sales promotion technique in appealingcustomers to make a preference in the incident of all the four classes of FMCG chosen for the study. Additional tools take exchangeableplaces. Consumer's perception about the efficiency for each sales promotion tools in encouraging them to make preference can be further examined according to the product category. As per the table 2 'price-off' seemsto be utmosteffective in the product coffee (mean value 33.043) and then products soap (mean value30.36), pulses (mean value 30.22) and shampoo (mean value 28.64) follow in that order.Couponing has highesteffect on the product pulses (mean value 15.34) followed by coffee (meanvalue13.9), shampoo (mean value 13.48) and soap (mean value 12.38). In the case of premium, the maximumeffect is on shampoo (mean value 20.79) followed by soap (mean value 18.22), coffee (mean value 18.0) and pulses (mean value 16.22). Impact of sampling on Consumer preference is at the maximum level on shampoo (mean value 17.2) followed by soap (meanvalue 17.32), pulses (mean value 17.24) and coffee (mean value 15.34). Finally, point-of-purchasepromotions employsupremeimpact on pulses (mean value 19.01) followed by shampoo (meanvalue 17.63), soap (mean value 18.43) and coffee (mean value 14.60). Standard 
deviation in all ofthe cases is less than the mean value and henceforth the outcomes are consistentbar in the case of POP

Analysis of Variance: A research of the significance of difference in the effectiveness of a salespromotion tool in inspiringpreference among the four products would be beneficial to themarketing manager to take suitableconclusions. Outcomes of the study of variance using ' $\mathrm{F}$ test' areobtainable in the Table 3. It can be perceived from the table that the motivational part of each salespromotion tool in building consumer preference in all the four products is not significantlydifferent as the ' $\mathrm{P}$ ' values in all the cases are more than 0.05 , at the confidence limit of $5 \%$.

Table 3:Results of Analysis of Variance (Inter-Product Analysis)

\begin{tabular}{|l|l|l|l|l|l|l|}
\hline $\begin{array}{l}\text { Sales Promotion } \\
\text { Tools }\end{array}$ & Source & $\begin{array}{l}\text { D.F } \\
\text { Pquares }\end{array}$ & $\begin{array}{l}\text { Square } \\
\text { Sum of } \\
\text { Mean }\end{array}$ & $\begin{array}{l}\text { F- } \\
\text { Ratio }\end{array}$ & P-Value \\
\hline Price-Off & Between Groups & 3 & 1461.4 & 491.8 & .963 & .429 \\
\hline Couponing & Between Groups & 3 & 318.1 & 105.3 & 1.074 & .384 \\
\hline Premium & Between Groups & 3 & 1215.4 & 408.3 & 1.819 & .175 \\
\hline Sampling & Between Groups & 3 & 68.0 & 22.0 & 0.103 & .937 \\
\hline POP & Between Groups & 3 & 1158.7 & 375.2 & 1.167 & .358 \\
\hline
\end{tabular}

Source: Survey Data

Table 4: Results of Analysis of Variance (Inter-Promotional Tool)

\begin{tabular}{|l|l|l|l|l|l|l|}
\hline Product & Sources & D.F. & $\begin{array}{l}\text { Sum of } \\
\text { Squares }\end{array}$ & $\begin{array}{l}\text { Mean } \\
\text { Square }\end{array}$ & F-Value & P Value \\
\hline Coffee & Between Groups & 4 & 26809.0 & 6727.2 & 27.4 & $<.001$ \\
\hline Shampoo & Between Groups & 4 & 16523.6 & 4118.4 & 15.9 & $<.001$ \\
\hline Pulses & Between Groups & 4 & 19174.3 & 4781.0 & 18.3 & $<.001$ \\
\hline Soap & Between Groups & 4 & 28147.1 & 7026.7 & 22.1 & $<.001$ \\
\hline
\end{tabular}

Source: Survey Data

It is detected that the efficiency of several sales promotion tools in building consumer preference inthe instance of the four products is different. These differences are againverifiedfor their 
significance by means of ' $\mathrm{F}$ - test' and the outcomes are given in the table 4. Ever since the ' $\mathrm{P}$ ' values in all the cases areless than 0.05 , at the confidence limit of $5 \%$, it is determined that the motivational role of the five techniques of promotion in building consumer preference in the instance of allthe four products isdifferent.

On the foundation of the above saidresults the subsequent null hypothesis is tested and the outcomes are givenas mentioned below:

Ho (1): There is no significant difference in the impact of important sales promotion techniques in customer preferences.

Ha (1): There is significant difference in the impact of important sales promotion techniques in customer preferences.

The Null Hypothesis Ho is rejected and the Alternative Hypothesis Ha that there is significant difference in the impact of important sales promotion techniques in customer preferences in the case of FMCG is proved and hence accepted.

\section{Suggestions:}

Based on the results of the study and the explanations of the investigator, the subsequentproposals are made for enhancing the effectiveness of sales promotion.

* The awareness level about several sales promotion techniques is very littlebar in the instance of Price-Off and Premium. It is recommended that sales promotion should be adequatelysupported by advertising.

* Customersdesire to get value added propositions like additional quantity of the product on same price. Extra pack method can be used more efficiently.

* Coupon circulationscheme should be rationalized, as customerstypicallydesire to get them.

* Price-off or discount strategy can be used to accomplish the short-term goals of promotion like brand switching, trial purchase, and stockpiling ahead of other schemes. 


\section{Conclusion:}

The results of this study deliver some valuableunderstandings in to the nature of effect ofseveral sales promotion techniques on different consumer behavior. The outcomes of the study on theimpact of sales promotion on purchasing and consumption behavior may be beneficial to marketersof FMCG companies to rationalize their sales promotion approaches and make theirpromotional exertions more productive.

\section{References:}

- Aggarwal, P. \&Vaidyanathan, R. (2003) Use it or lose it: purchase acceleration effects of time-limited promotions. Journal of Consumer Behaviour, 2(4), pp. 393-412.

- Ailawadi, K.L., Neslin, S.A. \&Gedenk, K. (2001) Pursuing the value-conscious consumer: store brands versus national brand promotion. Journal of Marketing, 65(1), pp. 71-89.

- Bawa, K. \& Shoemaker, R.W. (1987a) The coupons-prone consumer: some findings based on purchase behavior across product classes. Journal of Marketing, 51(4), pp. 99-110.

- Bawa, K. \& Shoemaker, R.W. (1987b) The effects of direct mail coupons on brand choice behavior. Journal of Marketing Research, 24(4), pp. 370-376.

- Bawa, K. \& Shoemaker, R.W. (1989) Analyzing incremental sales from a direct mail coupon promotion. Journal of Marketing, 53(3), pp. 66-78.

- Beerli, A. \& Martin Santana, J. (1999) Design and validation of an instrument for measuring advertising effectiveness in the printed media. Journal of Current Issues and Research in Advertising, 21(2), pp. 11-30.

- Belch, G.E. \& Belch, M.A. (2003) Advertising and Promotion: An Integrated Marketing Communications Perspective, 6th edn. Boston, MA: McGraw-Hill.

- Blattberg, R.C. \&Neslin, S.A. (1990) Sales promotion: Concepts, Methods, and Strategies. Englewood Cliffs, NJ: Prentice-Hall.

- Blattberg, R.C., Eppen, G.D. \& Lieberman, J. (1981) A theoretical and empirical evaluation of price deals for consumer nondurables. Journal of Marketing, 45(1), pp. 116-129.

- Gilbert, D.C. \&Jackaria, N. (2002) the efficacy of sales promotions in UK supermarkets: a consumer view. International Journal of Retail \& Distribution Management, 30(6), pp. 315322.

- Gupta, S. (1993) Reflections on the impact of sales promotions on when, what and how much to buy. Journal of Marketing Research, 30(4), pp. 522-524. 
- Haugh, L.J. (1983) Defining and redefining. Advertising Age, 14 February, p. 44. Helsen, K. \&Schmittlein, D.C. (1992) some characterizations of stockpiling behavior under uncertainty. Marketing Letters, 3(1), pp. 5-16. 